\title{
森林資源の利活用に関わる建築分野での環境負荷削減策に関する研究 \\ MFA・LCA を用いた全国及び広島県の環境動態分析 \\ WOODY RESOURCE UTILIZATION FOR ENVIRONMENTAL IMPACT REDUCTION WITH FOCUS ON BUILDING INDUSTRY
}

Dynamic analysis using material flow analysis and life cycle assessment in Japan and Hiroshima Prefecture

\author{
小林謙介*1, 若 林 國 久 ${ }^{* 2}$, 藤 津 浩 輝 ${ }^{* 3}$, 谷口 沙也佳 ${ }^{* 4}$ \\ Kensuke KOBAYASHI, Kunihisa WAKABAYASHI, Koki FUJITSU \\ and Sayaka TANIGUCHI
}

\begin{abstract}
With the aim of reducing environmental load, the life cycle of woody resource was studied using material flow analysis and lifecycle assessment. The targeted areas of study were the whole of Japan and Hiroshima Prefecture. All material flows along the life cycle of woody resource were developed in 2016. In view of LCA, the impact assessment showed that the largest load among those related to building industry was caused by the sluggish rate of reforestation. Therefore, taking measures to revitalize reforestation is of utmost importance. The next biggest impact was of the fossil fuel consumption in each process.
\end{abstract}

Keywords : Woody resource, Material flow analysis(MFA), Life cycle assessment (LCA), Dynamic Analysis of environment 森林資源，マテリアルフロー分析（MFA），ライフサイクルアセスメント (LCA)，環境動態分析

1 はじめに

\section{1 背景}

木材は、主要な建築材料の一つとして、欠かすことができない。 近年、戦後造林した人工林(スギ・ヒノキ)が大量に伐期を迎え、自給 率 $50 \%$ 目指して公共建築物等への国産材の利用拡大が推進され ている。そのため、ここ数年で森林資源利活用に関する動態が大き く変化してきている。森林資源は、適切な管理を行えば、持続的に 生産可能な資源と考えることができる。しかし、我が国における実 態は、再造林率が低迷しており、決して持続可能な状態とは言えな い。この状況を踏まえ、これまでに資源量に着目した将来推計を行 い利用後の再造林率（人口造林面積と立木主伐面積の比率）が低迷 （2010 年以降 34〜 41\%）1) したままでは資源が枯渇に向かう可能性 もあり得ることを明らかにし、適切な森林資源管理が必要なことを 示唆してきた2)。

森林資源の利活用方法を考えるうえでは上流・下流などの関連業 種を含め、木材のライフサイクルを通した分析が不可欠と考える。 しかし、林業・建築業・紙パルプ業などを結び付けた検討は多くは ない。また、森林資源の活用を取り巻く状況は、地域によって大き く異なる。従って、全国的なマクロな分析だけではなく、地域的な 視点での分析も非常に重要となる。特に、広島県は、西日本で最大
の森林面積を有している。一方、県産材の利用率が低く、用材生産 における輸入材の比率が非常に大きい3)。このため、県産材利用率 は、沖縄県に次ぐ全国 46 位の低さとなっている ${ }^{3}$ 。ままた、広島県内 の特徴として、森林資源を利用した複数の大規模なバイオマス発電 施設が計画されていることが挙げられる ${ }^{4}$ 。加えて、沿岸部と山間 部、山間部の中でも地域ごとに森林資源蓄積量の状況が大きく異な っていることが挙げられる5)

また、近年の環境問題への意識の高まりなどから、木材の利活用 に当たっても、より低環境負荷な形での利活用が求められる。しか し、環境問題は、資源枯渇（持続可能な生産）、地球温暖化、土地利 用など、様々な観点があり、それらの環境問題を総合的に評価した うえで、効率的な環境負荷低減策を検討した例は殆どない。環境影 響を定量的に分析する手法の一つに、ライフサイクルアセスメント （以下、LCA）がある。LCA を実施するためには、バックグラウン ドデータが必要不可欠である。近年、バックグラウンドデータベー ス IDEA Ver.2.26)が公表され、以前に比べて評価可能な環境負荷物 質が格段に充実してきており、 $\mathrm{CO}_{2} 、 \mathrm{CH}_{4}$ などの温室効果ガスや水 消費量だけではなく、約 200 種類の様々な環境影響を評価すること ができるようになってきた。

\footnotetext{
*1 県立広島大学生命環境学部環境科学科 准教授. 博士 (工学)

Assoc. Prof., Dept. of Environmental Science, Faculty of Life and Environmental

*2 県立広島大学生命環境学部環境科学科 客員研究員

*3 県立広島大学生命環境学部環境科学科 (研究当時)

$* 4$ 県立広島大学生命環境学部環境科学科 学部 4 年生

\author{
Science, Prefectural University of Hiroshima, Dr.Eng. \\ Guest Researcher, Dept. of Environmental Science, Faculty of Life and \\ Environmental Science, Prefectural University of Hiroshima \\ Dept. of Environmental Science, Faculty of Life and Environmental Science, \\ Prefectural University of Hiroshima \\ Dept. of Environmental Science, Faculty of Life and Environmental Science, \\ Prefectural University of Hiroshima
}




\section{2 目的}

本研究は、全国および広島県の森林資源のマテリアルフロー分析 (MFA) と環境影響評価 (LCA) を実施して、建築業だけではなく、 林業や紙・パルプ産業も含めた木材利活用のライフサイクルにおけ る環境負荷動態を明らかにすること、また、それらの環境影響を分 野横断的に俯瞰したうえで、建築分野に焦点をあてて、実施すべき 環境負荷削減策を検討することを目的とした。なお、1.1 背景でも 触れた再造林率の低迷などの課題はわが国における課題であり世界 全体が同じ課題を抱えているわけではない。そうした背景から、特 に国内での対策の検討に焦点を当てて分析を行った。

マテリアルフロー分析はデータが入手できる 2016 年の木材関連 統計などの公開統計資料を活用し、既存資料などから環境負荷量が 大きい丸太 (原木) や紙などは可能な限り細分化した。LCA は統合 化まで実施し、再造林率の環境影響のケーススタディを行った。

\section{3 既往研究}

森林資源に関するマテリアルフロー分析や LCA の既往研究は、 筆者らの文献 7)に整理して記述されている。橋本・森口 ${ }^{81}$ は、我が国 全体の伐採木材のマテリアルフロー分析を実施している。公開され ているデータは、1960 年から 2000 年まで、10 年ごとに作成され ており、動態を捉えることもできる。建築分野に焦点をあてた研究 として、天野・加用 9 による研究があり、製材や合板に着目した 2000 年の木材フローが報告されている。日本建築学会の文献 10)では、特 に建築用材として用いられる木材を中心に、製材・合板・集成材 • ボードなどについて細かい分析を行った、2005 年版のマテリアルフ ローが報告されている。このほか、筆者ら ${ }^{11)}$ にって 2000 年、2005 年、 2010 年のマテリアルフローの分析を実施し、動態を捉えている。 また、都道府県別などより対象を絞った報告例は、筆者らの 2012 年 の広島県を対象とした実態調查に基づく報告 2) があるが、報告例は 多くはない。

木材利活用における LCA は、育林・製材などの特定のプロセス の分析は数多く研究事例が見られる。一例を挙げると、森林施業に 関しては、栃木県内の森林組合や民間事業体を対象とし、ha あたり の施業に伴う $\mathrm{CO}_{2}$ 排出量を分析した有賀らの研究 ${ }^{12}$ がある。丸太の 生産には、一重・服部らの施業モデルごとに国産丸太のインベント リ分析を実施した報告 13)や、古俣らによるカラマツ丸太の例 14)があ る。素材の加工は、製材加工についてバイオマス熱源の利用状況な どによる $\mathrm{CO}_{2}$ 排出量の違いを検討した南部・伊香賀らの報告 ${ }^{15}$ )、長 野県を中心とした地域の木材加工の LCA を実施した高村・浅野ら の一連の研究 16-19)などがある。これらに対し、木材利活用のライフ サイクルを通した俯瞰的な評価は筆者らの文献 11,20)（ただし IDEA Ver.1を利用しており、現在とは大幅にデータの充実度が異なる）が あるが、それ以外の例は殆どない。

\section{2. マテリアルフロー分析 \\ 2.1 分析方法 \\ (1) 概要}

はじめに、全国および広島県を対象として、木材に関するライフ サイクルを通したマテリアルフロー分析を行った。筆者らは過去に

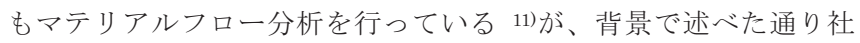
会・経済情勢の変化もあるので、2016 年版の直近で入手可能な木材
Table 1 Literatures for development of material flow

\begin{tabular}{|c|c|c|c|}
\hline Code & Reference & Japan & Hiroshima \\
\hline (1) & $\begin{array}{l}\text { Ministry of Agriculture, Forestry and Fisheries: http://www.rinya.maff. } \\
\text { go.jp/j/keikaku/genkyou/h29/index.html, (森林資源の現況) }\end{array}$ & 0 & 0 \\
\hline (2) & $\begin{array}{l}\text { Ministry of Agriculture, Forestry and Fisheries: Report on Supply and } \\
\text { Demand of Wood }\end{array}$ & 0 & 0 \\
\hline (3) & $\begin{array}{l}\text { New Energy and Industrial Technology Development Organization } \\
\text { (NEDO): http://app1.infoc.nedo.go.jp/biomass/biomas/download } \\
\text { /index.html, (バイオマス腑存量・有効利用可能量の推計) }\end{array}$ & 0 & 0 \\
\hline (4) & $\begin{array}{l}\text { Ministry of Agriculture, Forestry and Fisheries: Statistical Handbook of } \\
\text { Forest and Forestry, (森林林業統計要覧) }\end{array}$ & 0 & 0 \\
\hline (5) & $\begin{array}{l}\text { Ministry of Economy, Trade and Industry: Yearbook of Paper and pulp } \\
\text { statistics, https://www.meti.go.jp/statistics/tyo/seidou/result/ichiran } \\
\text { /08_seidou.html, (生産動態統計) }\end{array}$ & 0 & \\
\hline (6) & $\begin{array}{l}\text { Paper Recycling Promotion Center: http://www.prpc.or.jp/document } \\
\text { /publications/handbook/,(古紙ハンドブック) }\end{array}$ & 0 & \\
\hline (7) & $\begin{array}{l}\text { Ministry of Economy, Trade and Industry: Report by Industry of the } 2017 \\
\text { Census, https://www.meti.go.jp/statistics/tyo/kougyo/result-2.html, } \\
\text { (工業統計表) }\end{array}$ & 0 & 0 \\
\hline (8) & $\begin{array}{l}\text { Ministry of Land, Infrastructure, Transport and Tourism: Housing Starts, } \\
\text { ukei }=00600120 \& \text { tstat }=000001016966 \text {, (住宅着工統計) }\end{array}$ & 0 & 0 \\
\hline (9) & $\begin{array}{l}\text { Ministry of Finance: Trade Statistics of Japan, } \\
\text { http://www.customs.go.jp/toukei/info/index.htm, (貿易統計) }\end{array}$ & & 0 \\
\hline
\end{tabular}

需給報告書などの公開統計資料を用いて、木材産業活動におけるマ テリアルフローを構築した注1)。また、既往研究では行っていなかっ たが、生産量や環境負荷量が大きい丸太（原木）プロセスや紙の生 産プロセスをはじめ、Fig. 1、2 に示すような形で可能な限りプロセ スの細分化を図った。

\section{（2）全国のマテリアルフロー分析方法}

全国を対象としたマテリアルフローは、既報 11 で筆者らが 2000 年・2005 年・2010 年版を構築している。本フローは、紙など、森 林資源に関わるフローを俯瞰するため、紙・パルプ関連も含めたフ ローを作成した。

本検討では、Table 1 に示寸文献を用いて構築した。なお、森林資 源のプロセスには民有林だけでなく国有林も含めた。木材加工プロ セス（製材・合板）、木材製品の製造プロセス（ボード・建築用材）、 木材製品の消費プロセス（家具建具・建設用木材製品）は流通量が 多い製品を対象とした。製材・建築用材は引き角、合板は普通合板、 ボードはパーティクルボード、家具建具は木製棚、建設用木材製品 は木製流し台・調理台・ガス台のデータを用いた。

紙の製造プロセスは以下のように構築した。2016 年版の紙の生産 動態統計（Table 1 の(5)）を用いて、板紙類・紙類・紙おむつ・パ ルプに細分化した。板紙類の内訳は、段ボール原紙（内装用ライナ 一・外装用ライナー・中しん原紙) ・ 紙器用板紙・雑板紙とし、段ボ 一ル原紙は、内装用ライナー・外装用ライナー・中しん原紙に分類 した。また紙類の内訳は、新聞巻取紙、印刷・情報用紙、包装用紙 (未晒・半晒・晒)、衛生用紙、雑種紙とし、計 11 項目を合算した。

工場残材は、NEDO（国立研究開発法人 新エネルギー産業技術 総合開発機構）のバイオマス賦存量有効利用可能量の推計結果

(Table 1 の (3) ) を基に国産材製材廃材・外材製材廃材・建築廃材・ 新増築廃材・林地残材の数量を合算した。

\section{（3）広島県のマテリアルフロー分析方法}

広島県を対象とした分析には、小林らによる 2012 年版のマテリ アルフローの構築事例がある 2)。森林資源のプロセスは全国と同様 に民有林だけでなく国有林も含めた。紙の製造プロセスは、県内生 産量の多くを占める製紙事業者 2 社の公開データを基に分析した注 2)。塗工用紙・段ボール原紙（外装用ライナー・内装用ライナー・中 しん原紙)・板紙・さらし包装紙・情報用紙に細分化した。段ボール 
原紙は板紙の中に含まれるものとし、計 8 項目を合算した。県内で 製造された紙は全て県外に移出寸るものとした。その他のプロセス は基本的に(2)で記述した全国の構築方法に準じた。

\section{2 分析結果}

\section{(1) 全国の結果}

Fig.1 に、全国における 2016 年の木材マテリアルフローを示寸。 森林資源プロセスは立木換算值、丸太生産・丸太供給・木材加工 · 木材製品製造プロセスの值は丸太換算值、その他のプロセスは実量 值で示した（広島県のマテリアルフローも同様）。

国内資源は 5,230 百万 $\mathrm{m}^{3}$ だった。国産丸太生産量は 2,066 万 $\mathrm{m}^{3}$ で、 1,586 万 $\mathrm{m}^{3}$ (8 割弱) が建築用（製材・合板）に、480万 $\mathrm{m}^{3}(2$ 割強）が紙用であった。丸太輸入量は 537 万 $\mathrm{m}^{3}$ で、そのほとんど が建築用であった。チップ・パルプ輸入量は 2,531 万 $\mathrm{m}^{3}$ (丸太換 算)であった。国内での全利用量 5,132 万 $\mathrm{m}^{3}$ (国産丸太、輸入丸太、
輸入製品）の 4 割強が建築用（製材、合板）、6 割弱が紙用（チップ、 パルプ）あった。

建材は、製材用 $\left(1,218\right.$ 万 $\left.\mathrm{m}^{3}\right)$ が圧倒的に大きく、丸太供給量の 6 割弱を占めた。次いで、合板用 $\left(368\right.$ 万 $\left.\mathrm{m}^{3}\right)$ が 2 割弱だった。紙 の製造量は全体で 2627 万 ton、細分化した結果最も大きかったの はダンボール原紙の 936 万 ton だった。その内訳は、外装用ライナ 一-543 万 ton、中しん原紙 382 万 ton などだった。

\section{(2) 広島県の結果}

Fig.2 に、広島県における 2016 年の木材マテリアルフローを示 す。県内資源は 110 百万 $\mathrm{m}^{3}$ だった。県産丸太生産量は 339 千万 m3 で、147 千 $\mathrm{m}^{3}$ （4 割強）が建築用（製材・合板）に、192 千 $\mathrm{m}^{3}$ (6 割弱) が紙用であった。丸太輸入量は 1,770 千 $\mathrm{m}^{3}$ で、そのほと んどが建築用であった。チップ輸入量は 210 千 $\mathrm{m}^{3}$ (丸太換算) で あった。県内での全利用量 $2,319 千 \mathrm{~m}^{3}$ （県産丸太、輸入丸太、輸入

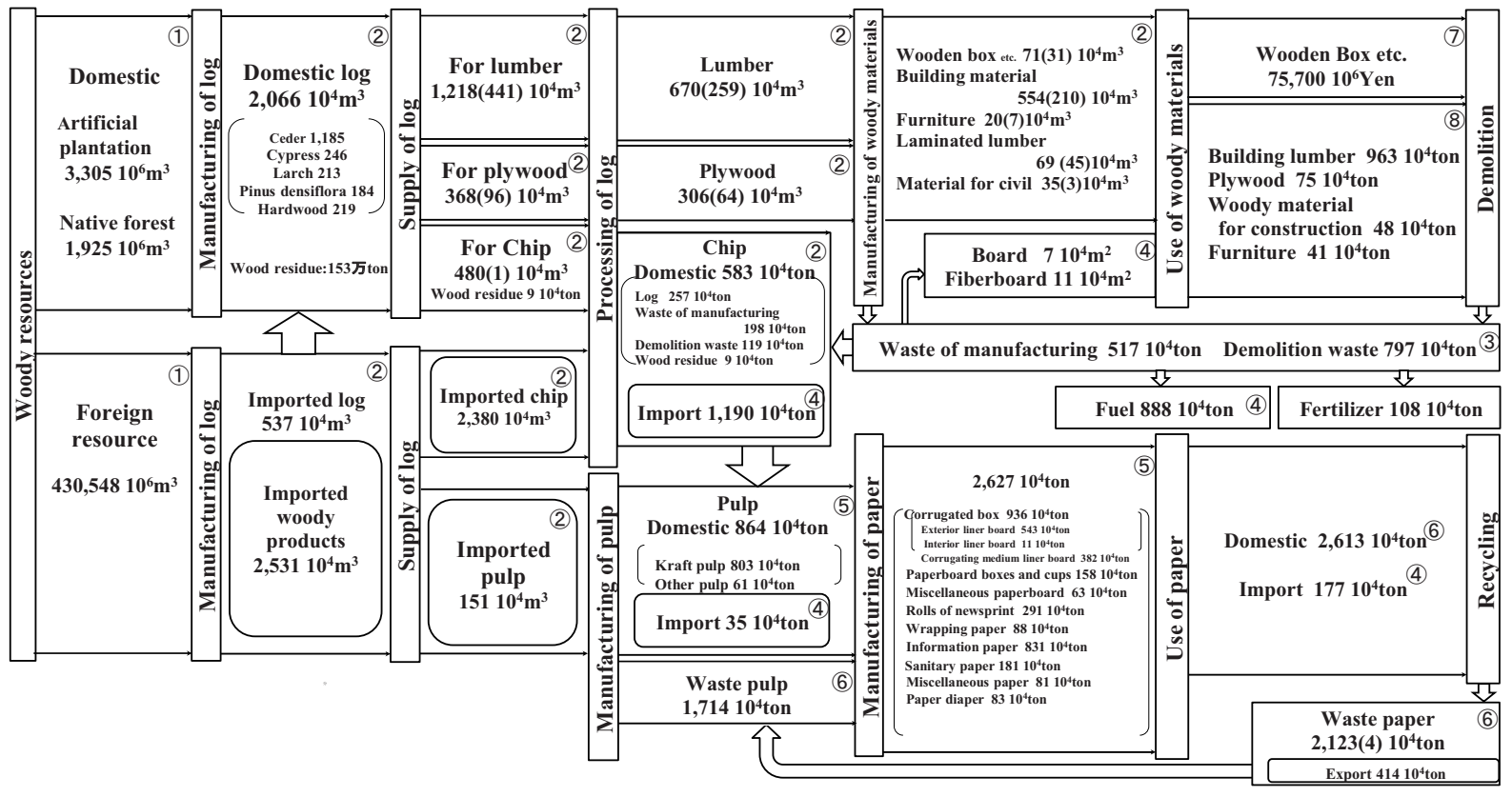

Fig.1 Material flow of woody material in Japan

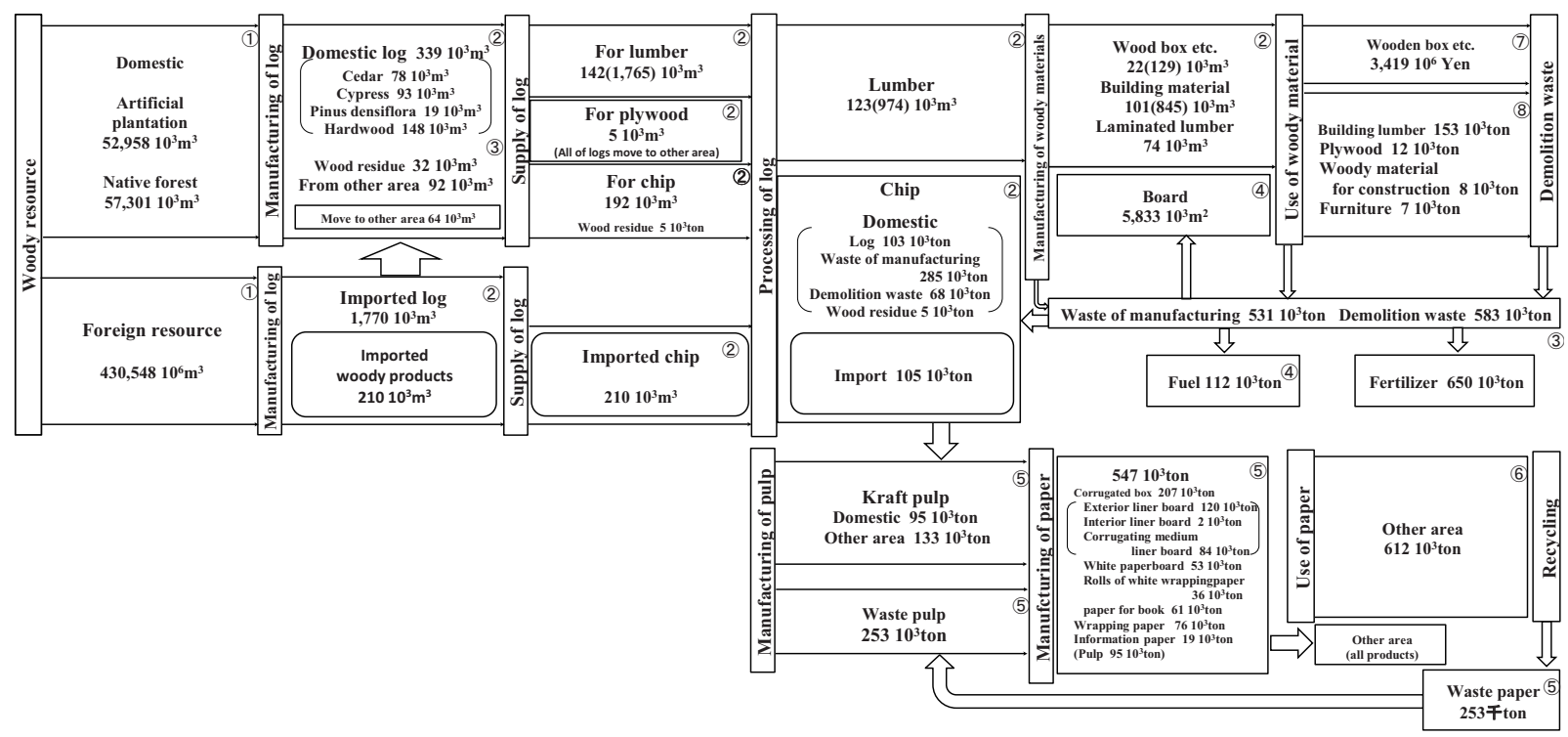

Fig.2 Material flow of woody material in Hiroshima 
製品）の 8 割強が建築用（製材、合板）、2 割弱が紙用（チップ、パ ルプ)であった。

県内の動態を見ると、建築関連では、合板工場はなく製材とチッ プが生産されているが、その殆どが製材であった。紙は 547 千 ton 生産された。細分化した結果、最大流量は 207 千 ton の段ボール原 紙でその内訳は、外装用ライナー120 千 ton、中しん原紙 84 千 ton などとなり、外装用ライナーが最も大きかった。

(3) 考察

資源の循環を検討寸るうえで、資源のフローを捉えることは不可 久である。本検討の結果、日本全体で見た場合、森林資源の出所で 見ると、全体では国産・輸入が半々程度を占めていた。また、広島 県も同様に県産材と輸入材がお括む敉半々程度であった。国産材は、 全国で見ると 8 割近くが建材利用であったが、広島県は 4 割強と、 大きく異なることが確認できた。こうした差異は、県内に立地する 規模の大きな生産施設の原料調達方針などに依存していると想像さ れる。

全国・広島県のいずれにおいても、国産材・県産材利用において 建材利用のために用いられる森林資源は少なくないことが確認でき た。我が国では、1.1 背景で示したように、森林資源の活用が叫ばれ る一方で、再造林率の低迷などが大きな課題の一つとなっている。 筆者らは文献 3)で我が国の森林資源は利用の仕方によって、今後余 剩となる場合もあれば、資源枯渴になる場合もあることを示した。 それを踏まえると、その森林資源を利用する立場として、余剩とな る場合は、特に流通量が多かった製材や合板などの積極的な活用が 求められ、不足が予想される場合は、材料の長寿命化や積極的なリ サイクルが必要になると考える。

\section{3. 環境負荷分析}

\section{1 方法}

構築したマテリアルフローからは、資源量の観点からの分析・考 察を行うことは可能であるが、それぞれのプロセスにおける活動に おいて発生する様々な環境影響を捉えることはできない。そこで、 構築したマテリアルフローを用いて、環境影響を定量する手法であ る LCA を実施した。例えば $\mathrm{CO}_{2}$ 排出量などの環境負荷物質の排出 量を計算するためには、投入原材料にそのバックグラウンドデータ (原単位) を乗ずることで計算できる。本分析では、バックグラウ ンドデータに我が国最大の Inventory Database for Environmental Analysis（IDEA） Ver. 2.26)を用いた。また、様々な環境負荷物質 排出量を環境への影響量（例えば温暖化）に換算するために、我が 国でよく用いられる日本版被害算定型環境影響評価手法 (LIME) 221)を用いた。

これまでに、筆者らが LCA の概算を行っているが、本検討では、 林業や紙・パルプ業を含めて作成したマテリアルフローのプロセス ごとに環境負荷排出量を算出し、支配的要因を明らかにしようとし ている点に新規性がある。また、最新の IDEA Ver.2.2 を用いること で、これまで評価ができなかった環境負荷物質が格段に増えた。具 体的には、Ver.1 の時は温室効果ガスなどごく限定的な環境負荷物 質が中心だったが、Ver.2.2 では約 200 種類の評価が可能となって いる。これにより多様な影響を考慮した評価ができている点に新規 性がある。本研究では、統合化・被害評価のそれぞれの段階で支配
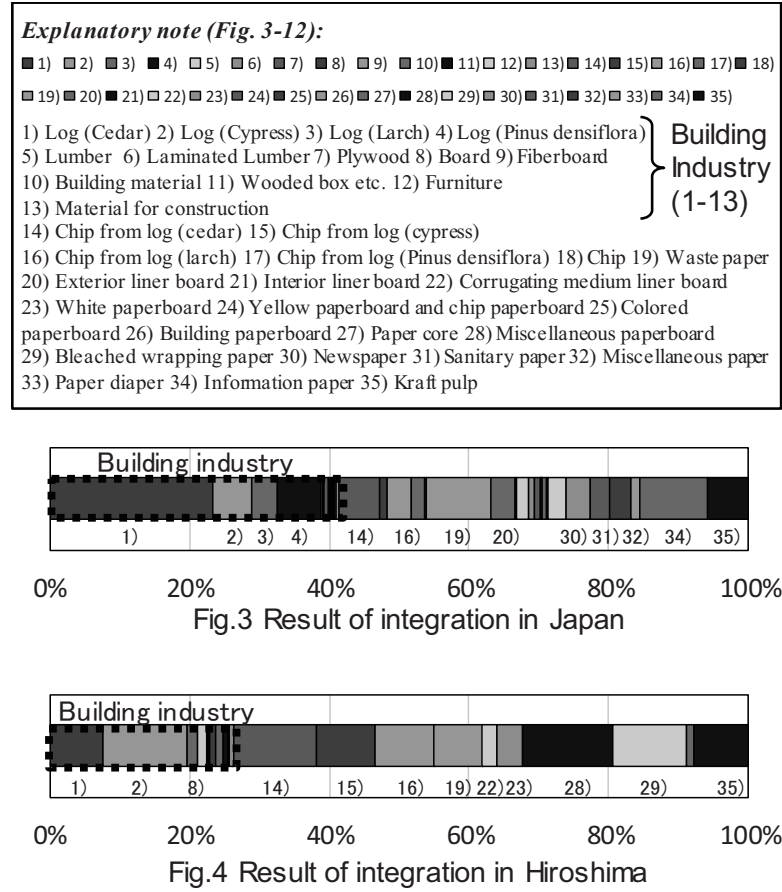

的要因を明らかにした。さらに、影響が大きかった環境負荷物質に ついて、詳細な分析を行った。なお、建築（製材・合板等）関係、 紙・パルプ関係などに分け、特に建築に起因する影響を中心に分析 した。

\section{2 分析条件}

評価範囲は丸太生産（育林から伐採）から木材製品生産までの生 産活動に伴う環境負荷排出量を対象とし、2.2 節で構築したマテリ アルフローのプロセスごとに算出した。なお、輸入される丸太生産 について、海外で発生する環境影響は評価対象外とした。これは、 再造林をはじめとする森林に関わる課題が国内外で大きく異なり、 本検討では国内を対象とした対策を検討しているためである。なお、 再造林率は、造林面積を伐採面積で除したものと定義した。全国の 再造林率の算出は、森林・林業統計要覧1)のデータを用い $35 \%$ と設 定した。広島県は伐採面積が不明なため広島県林業課にヒアリング した。また、造林面積は、林務関係行政資料 5)を用いて計算し、23.7\% と設定した。

\section{3 評価の限界}

本検討では、バックグラウンドデータとして IDEA Ver.2.2 を用 いた。また、影響評価のために LIME2 の係数を利用した。これら は、あくまでも日本の平均的なデータであることを目指して作成さ れている。従って、個別の事情をくみ取ればくみ取るほど誤差が生 じる可能性がある。また、筆者らが開発した IDEAの中には、決し て精度が高くないデータも含まれており、特に、 $\mathrm{CO}_{2}$ 以外の多様な 環境負荷物質は、精度が高くないものも少なくない。また、LIMEの 係数には幅があり、変動係数が大きいものもある。従って、あまり 細かい議論ができない。本検討においても大勢を捉えることを中心 に考察を進めた。

\section{4 統合化}

\section{(1) 統合化の考え方}

LCA における環境影響評価で、様々な影響を重みづけして単一の 指標として表現する方法があり、これを統合化と呼んでいる。本検 
討では、我が国でよく利用されている手法の一つである日本版被害 算定型影響評価手法 (LIME) 21)を用いて、検討を行うこととした。 統合化は、結果が単一指標となるため、解釈が容易であること、卜 レードオフの関係が発生しないことなどの利点がある。一方、環境 影響（被害評価）の重みづけは、自然科学に基づく知見から重みづ け係数が決定できないため、評価者の主観が入ったものとなる。そ こで、ここでは、参考として分析した。

\section{(2) 全国の結果}

Fig.3 に示寸ように、本条件下で最も影響が大きかったのは、スギ 丸太生産プロセスで、全体の 2 割強を占めた。次いで、情報用紙の 生産プロセスが続いたが、ヒノキやカラマツの丸太生産プロセスの 影響も大きかった。分野別にみると、建築起因が 4 割強、紙・パル プ起因が 6 割弱となった。

\section{（3）広島県の結果}

Fig.4 に示すように、建築起因が 2 割強、紙・パルプ起因が 7 割 強となった。これは、県内に製紙工場が複数存在していることによ ることも一因と考えられる。なお、広島県は、建材用の丸太は輸入 が極めて多いため、それらが国内と同じ影響であると仮定すると、 全体に及ぼす影響は極めて大きいと推察される。プロセス別でみる と、ヒノキの丸太生産プロセスが最も大きく 2 割近くを占めた。建 築利用の殆どはスギやヒノキなどの丸太生産プロセスが大きく寄与 する結果となった。

\section{(4) 考察}

統合化は、3.3(1)で述べたように、本結果のみから細かい議論は難 しいと考えられる。それを踏まえた上で、建築に由来する木材利用 の環境影響は、全国で 4 割強、広島県で 2 割強を占めた。2.2(3)で 述べたように、流通量ベースで見た場合は、全国で 8 割近く、広島 県で 4 割強であったため、それに比べると影響は小さいが、その影 響は無視できないものであることが分かった。また、流通量同様に 地域によって結果が大きく異なることも確認できた。

今回の検討ではプロセスを詳細に分けて検討した。建材利用され る森林資源は、いずれも丸太から製材のような加工工程ではなく、 丸太生産工程（全国ではヒノキ、広島県ではスギ）が大きいことが 分かった。いずれにおいても丸太を生産する工程での対策が不可欠 である。

\section{5 被害評価}

\section{(1) 被害評価の考え方}

被害評価とは、人間や生物種などの環境影響を受ける被害量を算 定寸るものである。本検討で用いた LIME2 では、人間健康・社会 資産・生物多様性・一次生産の 4 種類に整理される。ここでは、そ れぞれの評価結果を示す。

なお、一次生産とは、植物が光合成により有機物（有機物という 蓄積性のエネルギー)をつくり出すことを指している。一次生産は、 資源消費、オゾン層破壊、廃棄物などの影響が関係する。

\section{(2) 全国の結果}

一次生産とそれ以外で大きく傾向が異なった。一次生産は建築利 用が 7 割弱、紙利用が 3 割強で、建築利用の殆どは丸太生産が占め る結果となった（Fig.5）。統合化の結果で、丸太生産が大きな割合 を占めたのは一次生産による影響が大きいと思われる。また、人間 健康、社会資産、生物多様性は建築利用が 1 割弱、紙利用が 9 割強

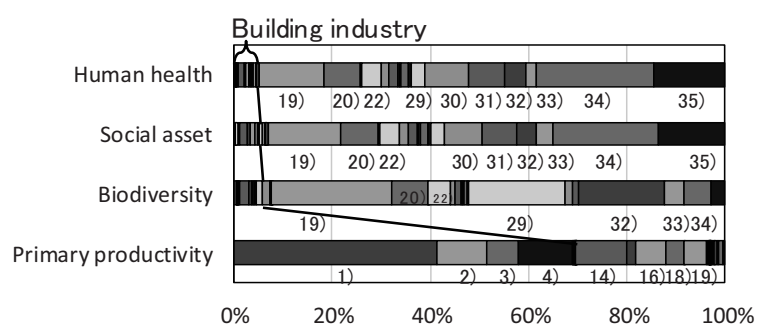

Fig.5 Result of damage assessment in Japan

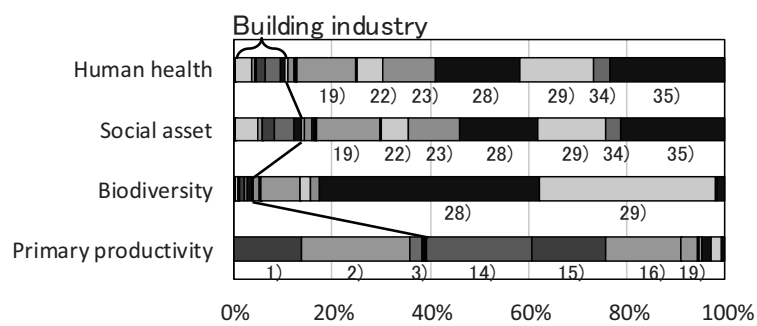

Fig.6 Result of damage assessment in Hiroshima

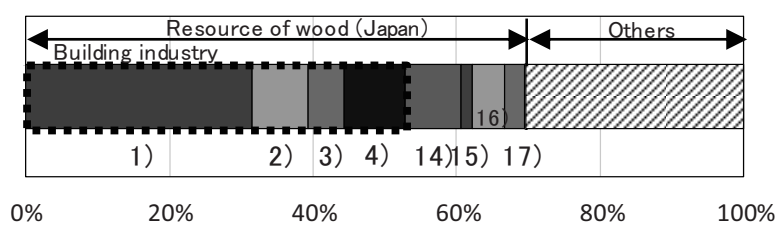

Fig.7 Detail of primary productivity in Japan

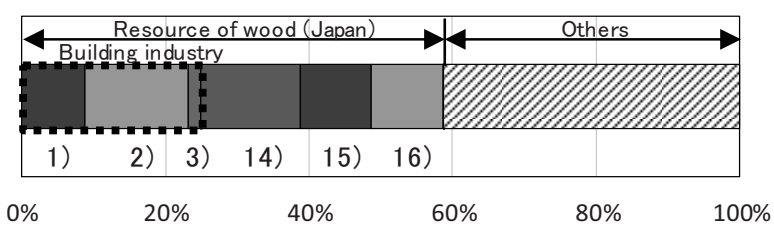

Fig. 8 Detail of primary productivity in Hiroshima

を占める結果となった。

（3）広島県の結果

全国の結果と同様に、一次生産とそれ以外で大きく傾向が異なっ た。一次生産は建築利用が 4 割弱、紙利用が 6 割強で、建築利用の 殆どは丸太生産が占める結果となった（Fig.6）。統合化で丸太生産 が大きな割合を占めたのは、一次生産による影響が大きいと思われ る。また、人間健康、社会資産、生物多様性は建築利用が 1 割強、 紙利用が 9 割弱を占めた。

\section{(4) 考察}

被害評価は、一次生産とそれ以外で大きく内訳が異なった。 3.4 節 で示した統合化の結果で丸太生産の割合が小さくなかったことから、 統合化の結果は一次生産による影響を強く受けていると推察される。 一次生産は建材起因となる影響が全国で 7 割弱と非常に大きく、県 産材の利用率が低い広島県でも 4 割弱と大きかった。特に丸太生産 工程（全国ではヒノキ、広島県ではスギ）が大きく、これらの環境 負荷削減が不可欠なことが分かった。

\section{6 一次生産に関する詳細分析}

\section{(1) 全国の結果}

Fig.7のように、全国の場合は、木材の資源消費による影響が全体 の 7 割を占めた。また、建築に起因寸る木材の資源消費が 5 割強を 占めており、非常に大きな影響であることが分かった。木材の資源 
消費は、資源の枯渇（将来世代にとって利用可能な資源が減少する ことによる影響) を指している。本検討結果では、木材の資源の枯 渴に対する影響が非常に大きく、これが、一次生産や統合化の結果 に大きく影響していることが分かった。

\section{（2）広島県の結果}

Fig.8のように、広島県の場合は、木材の資源消費による影響が全 体の 6 割近くを占めた。また、建築に起因する木材の資源消費が 3 割近くを占めており、その割合が小さくないことが分かった。

(3) 考察

木材利用に関する一連のプロセスにおいて、全体に対して大きな 影響を及ぼしている要因の一つは、木材の資源消費であることが分 かった。全国では 7 割を、広島県では 6 割近くを占め、いずれも大 きな割合となった。また、建材に限定すれば、スギやヒノキの影響 が特に大きい傾向となった。資源消費に関わる環境影響を軽減する ことを考えると、原木を得るために森林を伐採した後に、再造林を 行えば、枯渇の可能性はなくなり、環境負荷がゼロと捉えることが できる。すなわち、再造林率の向上が久かせないと言える。

\section{7 再造林に関する感度分析 \\ (1) 検討概要}

3.6 節では、一連の環境負荷発生量において、再造林率が大きく 影響することを示した。そこで、3.2 節で述べた方法で、建築起因の 木材の再造林率をパラメータ ( $0 \%$ 、現状 (全国: $35 \%$ ・広島県 : $23.7 \%$ )、 $50 \% 、 100 \%)$ にとり、その影響について、ケーススタディを実施す ることとした。なお、本検討は、建築分野での対策の検討とその効 果を推算することを目的とし、建築に関わる分野のみを対象として おり、紙・パルプ関連等は除いてケーススタディを行った。

\section{（2）全国の結果}

Fig.9 に全国の結果を示す。一次生産・統合化ともに、現状の再造 林率 $35 \%$ から $0 \%$ に下げると影響は 5 割強大きくなった。再造林率 $50 \%$ にげると影響は 2 割強小さくなった。伐採後の跡地にすべて 再造林 (100\%) すると、建築に起因する一次生産および統合化結果 への影響は殆どなくなる結果となった。なお、100\%の場合、化石燃 料消費の影響が大きくなった。

\section{(3) 広島県の結果}

Fig.10の通り、一次生産・統合化ともに、現状の再造林率 $23.7 \%$ から $0 \%$ に下げると影響は 3 割強大きくなった。再造林率 $50 \%$ に上 げると影響は 3 割強小さくなった。伐採後の跡地にすべて再造林 (100\%)すると建築に起因する一次生産および統合化結果への影響 は殆どなくなった。なお、 $100 \%$ の場合、化石燃料消費の影響が大き くなった。

(4) 考察

一連の木材ライフサイクルにおいて及ぼされる環境影響において、 全国・広島県ともに、木材利用における再造林率が非常に大きな影 響を及ぼしていること、また、再造林率が向上すればその影響は大 幅に改善されることが定量的に示された。再造林率の早期の大幅な 向上は、容易なことではないが、少しでも再造林率を向上させるこ とが重要である。仮に、再造林率を $50 \%$ にできれば、全国では 2 割 以上、広島県では 3 割以上削減可能で、大きな効果が期待できる。 再造林自体は林業従事者が行うが、その材料の消費者である建築側 は、再造林が担保されている材料を利用するなど、材料選択時の環

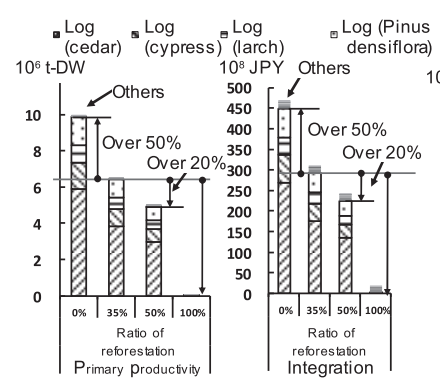

Fig. 9 Case study on reforestation (Japan)

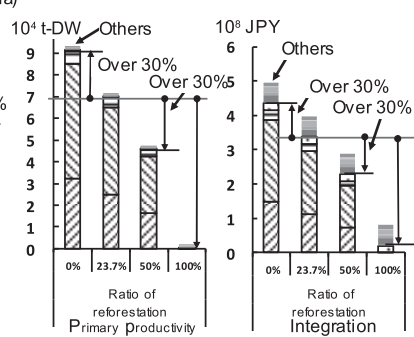

Fig. 10 Case study on reforestation (Hiroshima)

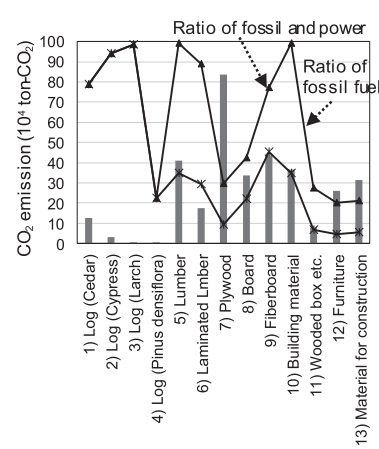

Fig. $11 \mathrm{CO}_{2}$ emission (Japan)

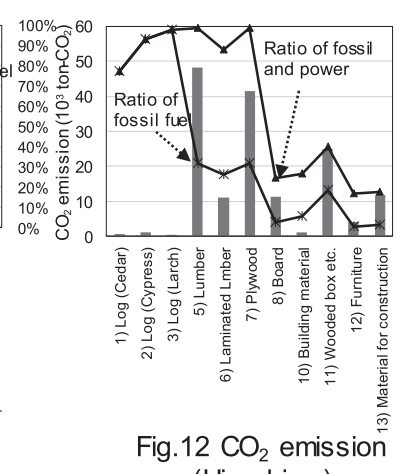
(Hiroshima)

境配慮が欠かせないと考える。

\section{$3.8 \mathrm{CO}_{2}$ 排出量}

\section{(1) 全国の結果}

3.7 節の感度解析では、再造林率の向上が見込まれれば、大幅に 環境負荷削減になることを示した。ただし、環境負荷は再造林に関 するものだけではない。再造林の影響が小さくなると、次に支配的 な要因となる項目は、化石資源の利用に関する内容となった。その ため、 $\mathrm{CO}_{2}$ 排出量について分析した。

\section{(2) 全国の結果}

Fig. 11 のように、建築起因の $\mathrm{CO}_{2}$ 排出量は 330 万 ton- $\mathrm{CO}_{2}$ 強で、 全体の 9 割強を木材製品が占め、丸太生産の影響は 1 割弱だった。 プロセス別では合板が 2 割強、製材、繊維板、ボード、建築用材ほ かが 1 割前後を占めた。また、各プロセスにおける化石燃料の燃焼 に伴う $\mathrm{CO}_{2}$ 排出量及び電力に伴う $\mathrm{CO}_{2}$ 排出量を分析した。その結 果、丸太生産では大半が化石燃料の消費だった。製材・合板等の生 産過程では、電力と化石燃料の消費の割合が大きかった。

\section{(3) 広島県の結果}

Fig. 12 のように、建築起因の $\mathrm{CO}_{2}$ 排出量は 16 万 ton- $\mathrm{CO}_{2}$ 弱で、 殆どを木材製品が占め、丸太生産の影響は極少だった。プロセス別 では製材が 3 割強、建築用材が 3 割弱、ボードが 2 割強、集成材ほ かが 1 割前後を占めた。また、丸太生産では大半が化石燃料の消費 だった。製材・合板等の生産過程では、電力と化石燃料の消費の割 合が大きかった。

\section{(4) 考察}

$\mathrm{CO}_{2}$ 排出量でみた場合、丸太生産プロセスよりも、製材や合板な ど丸太から製品へと加工寸るプロセスでの排出量がほとんどであっ た。全国では、合板加工プロセスが大きく、広島県では製材加工プ ロセス、次いで合板加工プロセスが大きい結果となった。丸太生産 プロセスでは、化石燃料の消費に起因寸るものが多く、これは、育 
林・伐採等における重機の利用が推察される。製材・合板等の加工 プロセスでは、当該プロセスで消費される電力と化石然料の消費の 割合が大きく、特に乾燥工程等で消費される熱の生産方法が重要に なると考えられる。

これらの利用者側である建築の立場では、こうした環境配慮を行 った製品の選択が重要になると考える。

\section{9 結果の考察}

以上のように、LCA を用いて環境影響の視点から定量的に分析し た結果、木材ライフサイクルに大きな影響を及ぼすプロセスは丸太 の生産プロセスにおける伐採後の再造林の有無であることが明らか になった。具体的に、国内を対象とした一次生産における再造林に 関わる影響は、全国で 7 割を、広島県では 6 割近くを占めた。また、 再造林に関する課題が解決すれば、一連の工程で発生する $\mathrm{CO}_{2}$ 排出 量の影響が大きくなった。特に丸太から製材や合板などへの加工プ ロセスの影響がほぼすべてを占め、丸太の生産プロセスは小さい結 果となった。加工プロセスでは、加工で利用される化石燃料の消費 量の削減が重要であることが分かった。

いずれにおいても、直接的に関わるのは、林業従事者や木材の加 工業者である。再造林の重要性は一般的にも認識されているが、林 業従事者だけでは早期の解決は難しいことも予想される ${ }^{2)}$ 。サプラ イチェーンの最終段階にある建築分野は一見関係ない上うに見える が、建築物に用いる材料を選択するのは施主や設計者らであり、そ れらの者たちの判断が環境影響を決定づけているともいえる。従っ て、消費する立場においてもこうした実態を十分に考慮するように することが重要と考える。

なお、本検討では、分析に IDEA Ver.2.2 や LIME2 を用いた。3.3 節でも述べたように、いずれの手法にも評価の限界はある。例えば、 資源消費は、資源の枯渴性を評価しているが、適切に管理すれば持 続的に生産が可能な木材は、再造林率と国産材利用量によっては、 将来余剩になるケースもあれば、不足する可能性があることもわか っている 2)。今後は、維持すべき供給可能水準などの議論も必要か と考える。

\section{4. まとめ}

本研究は、全国および広島県を対象に、森林資源のマテリアルフ ロー分析と LCA を実施して、木材利活用のライフサイクルにおけ る環境動態を明らかにすることを目的とした。また、一連の流れの 中で建築分野として実施すべき環境負荷削減策を提案するための検 討を行い、以下の内容を明らかにした。

1） 2016 年を基準年とする木材ライフサイクルに関わるマテリアル フローを構築した。構築したフローは、建築だけではなく、上流 の森林資源・丸太生産等のプロセスや紙・パルプに関する内容も 含めた。また流量が多いプロセスはできる限り細分化した。

国産・輸入についてみると、全国・広島県とも、半々程度だっ た。国産材は全国では 8 割近くが、広島県は 4 割強が建築用だっ た。このことから、国内の森林資源を取り巻く課題への対応にお いて建築材料の利活用の在り方が大きな力ギを握っていることも 確認できた。また、それぞれのプロセスにおける支配的要因を定
量的に明らかにできた。

2）構築したマテリアルフローをもとに、LCA を実施し、木材ライ フサイクルにおける建築分野での環境負荷削減策について検討し た。国内で発生する環境負荷を見ると、統合化は全国では 4 割強 が、広島県では 2 割強が建築起因となり、その影響は小さくなか った。いずれも、スギやヒノキの丸太生産（育林・伐採等を含む） プロセスの影響が大きかった。その内訳を被害評価の各カテゴリ で見ると、一次生産において、スギやヒノキの丸太生産の影響が 大きい結果となった。また、統合化も一次生産による影響が大き いことが分かった。人間健康・社会資産・生物多様性は紙・パル プ関係に起因する影響が大きかった。更に、環境影響評価物質ご とに詳細を分析したところ、木材の資源消費の影響が極めて大き いことが示された。

3）評価結果を踏まえ、再造林に関する感度解析を行った。その結果、 再造林率の影響が極めて大きいことを示した。本検討では、全国 が $35 \%$ 、広島県が $23.7 \%$ と設定したが、これらの改善が必要不可 欠との結果になった。また、再造林率の課題が解決できた場合、 次に大きな影響を有するのは、各プロセスで消費される化石燃料 であった。このことから、木材加工等における化石燃料利用量の 削減も非常に重要な課題であることを示した。

森林資源が製材や合板など建築材料として生産されるまでには、 様々なステークホルダーが関係する。今回の評価結果は、林業や材 料の生産者のみが責任を負うべき問題ではないと考える。

建築分野は木材ライフサイクルの下流側にあたるが、建築分野で 消費される材料選択が、森林資源利用による環境負荷量に大きな影 響を及ぼすからである。この点を認識し、最終消費者である施主や 設計者等が材料選択を行うことが重要と考える。また、具体的には、 再造林が担保されている材料を利用することは非常に重要な要素と なると考える。更に、 $\mathrm{CO}_{2}$ 排出量の削減の視点では、生産過程にお いては、天然乾燥などできる限り化石燃料を利用せずに生産された 材料を選択することが重要と考える。このほか、再造林や $\mathrm{CO}_{2}$ 排出 量の対策が担保されていることを示寸仕組みが一般的な形で認識さ れることも重要である。 
注

注 1）本マテリアルフローに含まれない内容として、椎茸原木や燃料材がある。全 国で椎茸原木は 328 千 $\mathrm{m} 3$ 、燃料材は 5807 千 $\mathrm{m} 3$ となっており、フロー全体に占 める割合は大きくない。このことから、本マテリアルフローは、森林資源の殆どを 網羅出来たフローになっていると考えられる。

注 2）広島県内において大規模な製紙工場はこの 2 社のみである。わずかに中小の 規模で段ボール等を生産する事業者があるが、この 2 社でほぼ $100 \%$ と考えられる。

\section{参考文献}

1) Ministry of Agriculture, Forestry and Fisheries: Statistical Handbook of Forest and Forestry, 2016 and 2018 (in Japanese)

農林水産省 : 森林・林業統計要覽 2016, 2018

2) Kensuke Kobayashi et al: STUDY ON EFFECTIVE FOREST MANAGEMENT IN HIROSHIMA PREFECTURE, Dynamic analysis of future changes in forest resource, estimated based on a questionnaire survey, Journal of Environmental Engineering (Transactions of AJJ), 81, 744, pp.215-224, 2018.2 (in Japanese)

小林謙介, 坂神慎一, 若林國久: 実態調査に基づく広島県における森林資源の需給 分析 アンケート調査に基づく動態分析と森林資源量の将来推計, 日本建築学会 環境系論文集, 81, 744, pp.215-224, 2018.02

3) Ministry of Agriculture, Forestry and Fisheries: Statistical Handbook of Forest and Forestry, 2014 (in Japanese)

農林水産省: 森林・林業統計要覧, 2014

4) Hiroshima gas Co., Ltd., http://www.hiroshima-gas.co.jp/com/w_new/release /2017/bio0728.htm, (accessed 2019-04-08)

広島ガス: http://www.hiroshima-gas.co.jp/com/w_new/release/2017/bio0728.htm, (参照 2017-04-06)

5) Hiroshima Pref., https://www.pref.hiroshima.lg.jp/site/toukei/hiroshimaringyoutoukei.html, (accessed 2019-04-08)

広島県: 林務関倸行政資料, https://www.pref.hiroshima.lg.jp/site/toukei

/hiroshimaringyou-toukei.html, (参照 2019-04-08)

6) Research Laboratory for IDEA, National Institute of Advanced Industrial Science and Technology, https://www.aist-riss.jp/groups/idea/, (accessed 2019-0408)

7) Kobayashi, K: Material Flow Analysis and Life Cycle Assessment for Utilization of Woody Resources in Buildings, Mokuzai Gakkaishi, Vol. 61 (3), pp.111-116, 2015.5 (in Japanese)

小林謙介：建築における木質資源の利活用にかかわるマテリアルフローと LCA, 木材学会誌 61 巻 3 号（60 周年記念号）, pp.111-116, 2015.5

8) Hashimono, S. and Moriguchi, Y: Material Flow Data Book -World Resource Flows around Japan-, National Institute of Environmental Studies, Center for Global Environmental Research, 2004

橋本征二, 森口祐一: 日本における伐採木材のマテリアルフロー・炭素フローデー タブック, 国立環境研究所 地球環境研究センター, 2004.

9) Amano, K. and Kayo, C.: Carbon Mass Balance Related to Architectural Wood Based on Material Flow Analysis, Environmental System Research, Vol.32, pp.57-63, 2004 (in Japanese)

天野耕二, 加用千裕: マテリアルフロー分析に基づいた建築分野における木材の炭 素収支について, 環境システム研究論文集 Vol.32, pp.57-63, 2004

10) Architectural Institute of Japan: Material Flow Analysis and Issues on use of Building Material, 2008.3 (in Japanese)

日本建築学会 地球環境委員会 資源利用戦略小委員会: 建築材料のマテリアル フローと資源利用の課題, 2008.3

11) Kobyashi, K., Nakajima, S., Tsunetsugu, Y., and Ikaga, T.: Analytic Study on Woody Material Flows in view of Carbon Reduction, Journal of Environmental Engineering (Transactions of AIJ), Vol. 76 , No.659, pp.91-96, 2011.1 (in Japanese)

小林謙介, 中島史郎, 恒次祐子, 伊香賀俊治: 建築における木質バイオマスの有効 利活用に関寸る研究, 日本建築学会環境系論文集 No.659, pp.91-96, 2011.1

12) The Japanese Forest Society, https://www.jstage.jst.go.jp/article/jssc/121/0 /121_0_227/_pdf/-char/ja, (accessed 2019-04-08) 有賀一広, 小松崎未来, 斉藤仁志, 伊藤 要, 村上文美, 武井裕太郎, 仲畑 力, 永野 格, 山口鈴子, 田坂聡明 : 栃木県の林業作業における $\mathrm{CO} 2$ 排出量算定と収 支分析, 日本森林学会第 121 回大会, F29, 2010
13) Kyoichiro Hitoe et al.: Case Study of Life Cycle Assessment of Domestic logs, Mokuzai Gakkaishi, 59 (5), 269-277, 2013

一重喬一郎, 長谷川隆大, 長谷川香織, 寺澤健治, 山中一憲, 服部順昭: 国産丸太 のライフサイクルアセスメント事例, 木材学会誌 59 (5), 269-277, 2013

14) Hirotaka Komata et al.: Inventory Analysis of CO2 emission for Log Production of Japanese Larch, Journal of Life Cycle Assessment Japan, 5(1), 131-137, 2009.1

古俣寬隆, 由田茂一, 加藤幸浩, 高山光子: カラマツ丸太生産における CO2 排出 のインベントリ分析, 日本LCA 学会誌 5 (1), 131-137, 2009.1

15) Yusuke Nambu et al.: Developing a LCA Database of Wood Materials, AIJ Journal of Technology and Design, 20, 38, pp.269-274, 2012.2 (in Japanese) 南部佑輔, 伊香賀俊治, 本藤祐樹, 小林謙介, 恒次祐子：建築用木材の LCA デー タベースの構築，日本建築学会技術報告集 38 号, pp.269-274, 2012.2

16) Keita MATSUBARA et al.: Investigation Concerning Life Cycle Assessment of Worked Timber - Japanese larch glued laminated timber of eastern Nagano Prefecture -, AIJ Journal of Technology and Design, 20, 45, pp.819-824, 2014.6 (in Japanese) 松場啓太, 浅野良晴, 高村秀紀, 早川慶朗: 加工木材のライフサイクルアセスメン 卜調査-長野県東信カラマツ集成材の場合-. 日本建築学会技術報告集, 20,45 , pp.819-824, 2014.6

17) Yuiki Ido, et al.: Comparison of Gifu and Nagano's Local Woods in Japanese Alps, Basic research of the life cycle assessment of local wood that is used in the construction of house Part 3, Journal of Environmental Engineering (Transactions of AIJ), 79, 698, pp.357-364, 2014.4 (in Japanese) 井戸結貴, 浅野良晴, 高村秀紀, 早川慶朗: 日本中部山岳域における岐阜県産材と 長野県産材の比較 地場産材を使用した住宅における木材のライフサイクルアセス メントに関する基礎調査 その3.日本建築学会環境系論文集 79,698,pp.357$364,2014.4$

18) Hideki Takamura, et al.: Research into the Life cycle assessment of Japanese cedar in Niigata Prefecture used in Wooden House, AIJ Journal of Technology and Design, 20, 44, pp.423-428, 2014.2 (in Japanese)

高村秀紀, 浅野良晴, 櫻庭瞳, 上田智輝, 早川慶朗: 木造住宅に使用される新潟県 産スギのライフサイクルアセスメント調査. 日本建築学会技術報告集 20,44 , pp.423-428, 2014.2

19) Ryuichi Yamagata, et al.: A Calculation of the Carbon Balance of Nagano's Local Wood, Japanese Cedar and Japanese Larch, Basic research of the life cycle assessment of local wood that is used in the construction of houses Part 2, Journal of Environmental Engineering (Transactions of AIJ), 78, 683, pp.73-79, 2013.1 (in Japanese)

山形龍一, 浅野良晴, 高村秀紀: 長野県産スギ, カラマツのカーボンバランスの算 出 地場産材を使用した住宅における木材のライフサイクルアセスメントに関する 基礎調査 その 2 , 日本建築学会環境系論文集 78, 683, pp.73-79, 2013.1

20) Kobyashi, K. and Wakabayashi, K. Sustainability Managed Forestry from the Perspective of Building Industry, Journal of Environmental Engineering (Transactions of AIJ), Vol. 81, No.720, pp.255-261, 2016.2 (in Japanese) 小林謙介, 若林國久: 建築における環境面からの木材の有効利活用に関する研究 全国及び広島県の動態分析, 日本建築学会環境系論文集 No.720 pp.255-261, 2016.2

21) Norihiro ITSUBO, Atsushi INABA: Life-cycle impact assessment method based on Endpoint modeling, Japan Environmental Management Association for Industry, 2010.3

伊坪徳宏, 稲葉敦: LIME2 意思決定を支援する環境影響評価手法, 産業環境管理 協会, 2010.3 


\section{WOODY RESOURCE UTILIZATION FOR ENVIRONMENTAL IMPACT REDUCTION WITH FOCUS ON BUILDING INDUSTRY}

Dynamic analysis using material flow analysis and life cycle assessment in Japan and Hiroshima Prefecture

$$
\begin{gathered}
\text { Kensuke KOBAYASHI }{ }^{* 1} \text {, Kunihisa WAKABAYASHI }{ }^{* 2}, \text { Koki FUITSU }^{* 3} \\
\text { and Sayaka TANIGUCHI }
\end{gathered}
$$

${ }^{* 1}$ Assoc. Prof., Dept. of Environmental Science, Faculty of Life and Environmental Science, Prefectural University of Hiroshima, Dr.Eng.

${ }^{* 2}$ Guest Researcher, Dept. of Environmental Science, Faculty of Life and Environmental Science, Prefectural University of Hiroshima

${ }^{* 3}$ Dept. of Environmental Science, Faculty of Life and Environmental Science, Prefectural University of Hiroshima

${ }^{* 4}$ Dept. of Environmental Science, Faculty of Life and Environmental Science, Prefectural University of Hiroshima

This study was aimed to clarify the environmental dynamics in the life cycle of woody resource and its utilization through material flow analysis and lifecycle assessment, which were focused on the areas of Japan nationwide and Hiroshima Prefecture. In addition, from the viewpoint of the party involved in building industry, discussion was made about effective measures for environmental impact reduction. The results were as follows:

\section{1) Material flow analysis}

A set of material flows was developed as of the year 2016 to represent the whole life cycle of woody resource, which actually included processes in building industry, forestry and lumbering, and pulping and paper making. Also, as for processes with large outputs, they were subdivided into as many segments as practically possible.

The results showed that, in comparison to the Japan (nationwide, 2010) and Hiroshima Prefecture (2012) respectively in the amount of lumber consumption, the outputs of our study (2016) showed only slight increase; and also that, in each area of Japan and Hiroshima, the ratio between domestically produced to imports was nearly 1 to 1 . However, as for consumption of domestic lumber, nearly $80 \%$ of it was used for buildings in Japan and only a little more than $40 \%$ in Hiroshima. This clear-cut difference suggested that most careful consideration should be given to way of resource utilization in building industry. In addition, the material flows developed in this study helped reveal the dominant factor in each process quantitatively.

\section{2) Lifecycle assessment}

Based on the developed material flows, the environmental loads were calculated by using LCA, and thus way to reduce the loads in the building industry was discussed. In the outputs from Integration, which is a single index, the loads caused by woody resource used for buildings were a little over $40 \%$ in Japan, and more than $20 \%$ in Hiroshima Pref. In both cases, the dominant factor was log manufacturing or the process segment of growing cedar and cypress trees which includes foresting and harvesting. The results of damage assessment, which is composed of the four safeguard subjects (human health, social asset, biodiversity and primary productivity), showed that in the primary productivity the same segment was most responsible for the damages and that it affected integration significantly. And the dominant factors of primary productivity were consumption of woody resources of cedar and cypress. In view of other subjects, almost all impacts were caused by paper and pulping industry.

Based on the results of the impact assessment, sensitivity analysis on the log manufacturing process was examined. As a result, it showed that the influence of the reforestation rate was extremely large. In this case study, it was set at $35 \%$ in Japan Nationwide and $23.7 \%$ in Hiroshima Pref. Therefore, these improvements resulted in being indispensable. If the issue of reforestation rates could be solved, the next biggest impact would be the fossil fuel consumption in each process. This suggest that reduction in fossil-fuel consumption in the lumbering process should also be very important. 